\title{
El patrimonio inmueble de Aranjuez. Su evolución en el siglo XIX *
}

\author{
Ma Magdalena Merlos Romero
}

Desde el siglo XVI hasta el XIX Aranjuez es el idílico paraíso de la monarquía española. Carlos I pretende crear una especie de villa imperial de recreo que no llega a cuajar. Será su hijo Felipe II el gran organizador del espacio presidido por el sentido de la amenidad. Existía ya una afición de nuestra monarquía a la caza desde los siglos bajomedievales ', que localizaba los escenarios de caza en zonas próximas al Tajo. Así surge el Real Sitio, donde los agradables días primaverales consolidarán las conocidas Jornadas. El siglo XVIII sumará a esta primera finalidad de recreo un proyecto de utilidad pública acorde con las ideas ilustradas ${ }^{2}$ y creará una población en torno al Palacio. Aranjuez núcleo urbano, con una dimensión añadida a la meramente cortesana comienza a forjarse coincidiendo con el paso del siglo XVIII al XIX.

\section{DE LOS ORÍGENES AL REINADO DE CARLOS IV}

El origen del Real Sitio de Aranjuez se sitúa en la Edad Media, cuando el territorio conquistado al Islam pasa a la Orden de Santiago ${ }^{3}$. En 1489 ,

* El presente estudio se basa en otro más amplio presentado en el Departamento de Historia del Arte, en el que se analiza además la evolución conceptual y juridica del Patrimonio.

A. Dominguez Ortiz, "Los primeros borbones españoles y los Reales Sitios", El Real Sitio de Aranjuez y el Arte Cortesano. CAM-PN. Madrid, 1987, págs. 11-15; J.M. Morán Turina y F. CHECA CREMADES, Las casas del Rey. Casas de campo, cazaderos y jardines siglos xVI y xyII. Madrid, 1986.

* Citemos los modelos agricolas y ganaderos, respectivamente, de El Cortijo y Sotomayor. A. Ponz, Viaje de España, ed. fac. Madrid, 1988, 1. pág. 96, 381-383, 506-508; V. Tovar Martin, "Consideración al valor de lo "rústico" en los Sitios Reales (reinado de Carlos III)", Fragmentos $\mathrm{n}^{\circ}$ 12-13-14 (1988), págs. 219-231; J.A. AlvafEz dE Quindos, Descripción histórica del Real Bosque y Casa de Aranjuez. Madrid, 1804. Ed. fac. Aranjuez, 1993, pág. 380. 


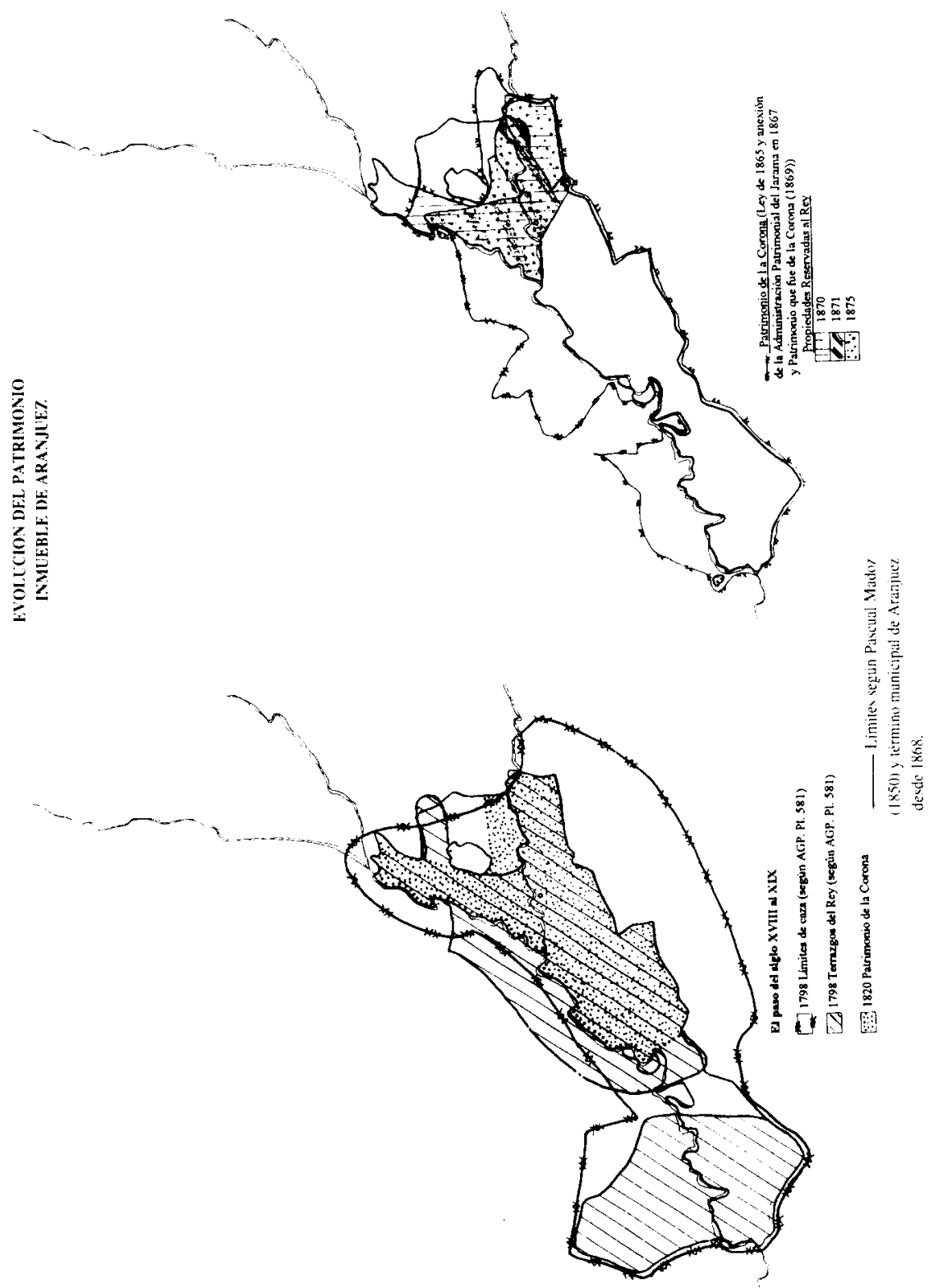




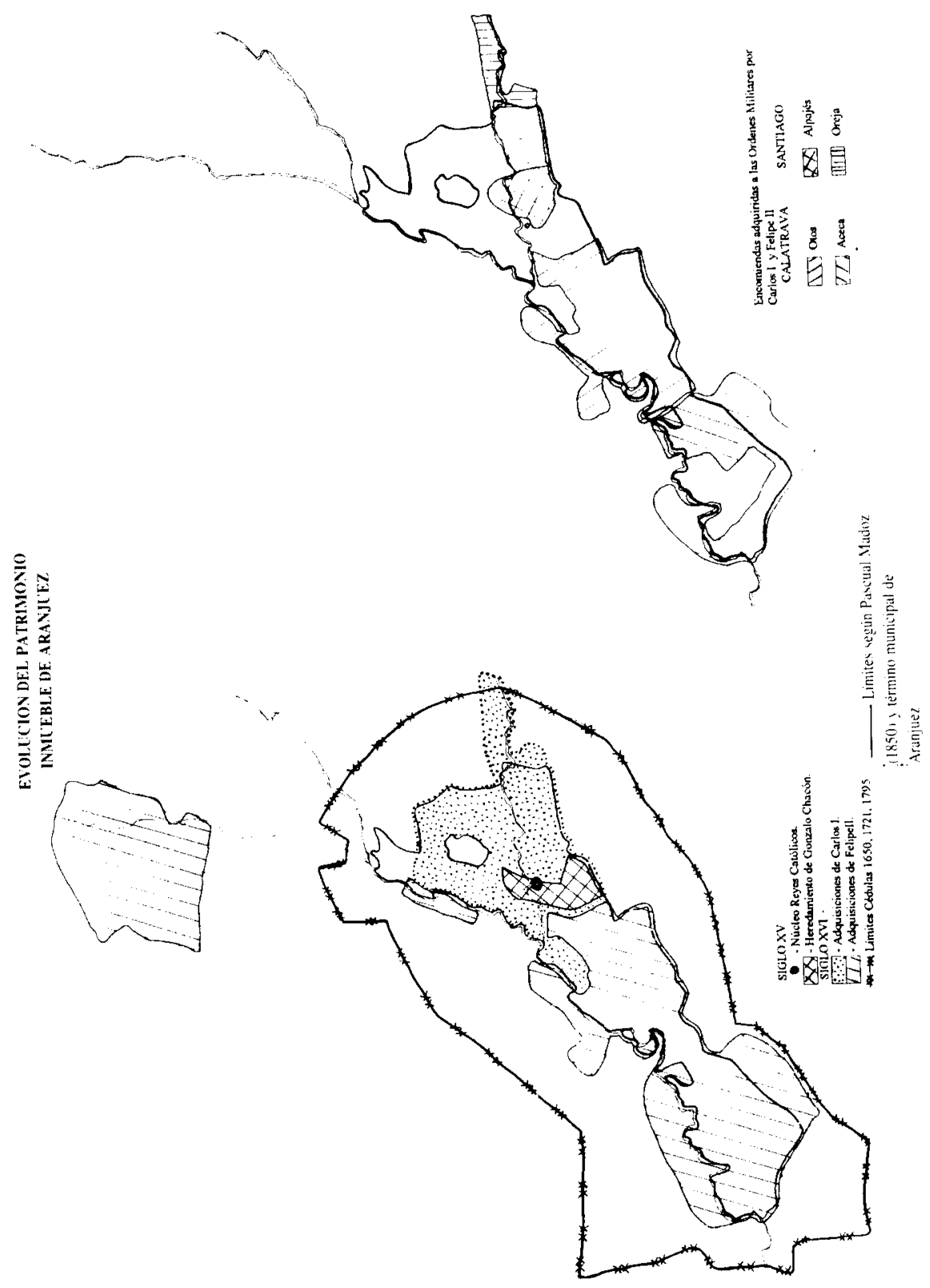


con los Reyes Católicos, se incorpora a la Corona la Casa Maestral, núcleo inicial al que se añadirán otras propiedades en manos de concejos, órdenes militares o nobles.

Las posesiones de la Monarquía en Aranjuez deben entenderse como una acumulación de bienes por su intrínseca riqueza, por su idoneidad para el recreo, por su significado añadido como símbolo de prestigio. Tan vasto territorio se delinea mediante un criterio de selección dirigido hacia Toledo por la caza, hacia el Norte por la conexión fluvial vía Jarama con Madrid.

\subsection{Los Austrias ${ }^{4}$}

Una Real Cedula de 28 de septiembre de 1534 destinará para recreo de Carlos I la Dehesa de Aranjuez, con la prohibición de su uso para pastos. El cronista Quindós relata:

"Este fue el principio del Real bosque de Aranjuez, y quando se empezó á guardar la caza de él para la real diversión: y considerando que eran muy cortos sus limites para el fin que se proponia, determinó ensancharlos y dilatarlos quando fuese posible, reuniendo los terrazgos inmediatos, tanto de las Ordenes Militares, como de particulares y pueblos vecinos".

La Encomienda de Alpajés será la primera en integrarse en 1536. Perteneciente a la Orden de Santiago, comprendía la dehesa del mismo nombre, las del Rebollo y Gulpijares y las salinas de Alpajés. La Encomienda de Oreja (Dehesas de Sotomayor y de El Parral). también santiaguista, se integrará en 1540 y el Heredamiento de Gonzalo Chacón (El Regajal -entorno del Mar de Ontígola--, El Rebollo, La Huelga) en 1543.

Es el momento en que se incorporan, además, hacia el Oeste del núcleo original, la Dehesa de Requena y Chachavillas. La expansión hacia el Norte incluye la Puebla de Forcajada (Sotogordo), la Dehesa del Redondillo y el añadido de San Juan del Burgo, ya hacia Villaconejos y Chinchón. Otras tierras irán encaminadas a completar las propiedades entre las citadas encomiendas: las Tierras de Vadillo, Escaleruelas y Valdelascasas, prolongándose las adquisiciones hasta la Dehesa de Biedma (la intermedia Dehesa de Valdajos se integrará con Felipe II).

\footnotetext{
4 Ibidem, págs. 72-168. En las ampilaciones la Dehesa de El Parral se devolverá a los pueblos de Oreja, Colmenar y Noblejas. Quindós recoge los limites que señala Francisco Ruiz Osorio, contador del Real Sitio, siendo muchos más amplios en cuanto a derechos.
} 
Durante el reinado de Carlos I, su hijo aún príncipe, ampliará los limites a costa de otra Orden Militar, la de Calatrava, con la intención de enlazar con los Montes de Toledo, siempre en busca de la caza mayor. Se trata de las Encomienda de Otos (1534-1535) y de Aceca. La primera estaba constituída principalmente por las Dehesas de Alhóndiga y de Higuera, ambas en la margen derecha del río, y la de Otos, en la margen izquierda. La segunda, en la que se levanta el desaparecido palacio de Aceca, lindaba con los términos de Villaseca y Velilla. Estaba integrada por los millares de los Prados, de la Barca, Madre Vieja, Ortigal, Cinco-Yugos (término de Yepes), Dehesa de la Torre (hoy de Villasequilla de Yepes) y Villamejor.

Felipe II, ya rey, ampliará la zona con la Dehesa de Villamejor, el prado de Martín Román, parte de Mazarabuzaque y la Dehesa de Barciles. Hacia el Norte, y en relación con el proyecto de la acequia del Jarama, agregará a continuación de la Puebla de Forcajada el Soto del Xembleque (1587) (actual término de Seseña) y el Soto de las Cuevas. Remontando el Jarama llegará a incorporar en 1572 - véanse las impresionantes dimensiones-Gozquez y Santisteban (actualmente en San Martín de la Vega), Aldehuela y Burueño (del término municipal de Getafe hoy en día), Vaciamadrid, Pajares (entre San Martín, Morata y Arganda), el Soto del Piul y las islas del Jarama. Hacia el Sur, en las proximidades de Ocaña, las incorporaciones en 1571 de los parajes de Aldehuela, Menalgavia, Valhondo y Aljibejo, supondrán los mayores límites del Real Sitio.

\subsection{Los Borbones}

Los límites y términos del cazadero se irán reduciendo. Fundamentales resultan las Reales Cedulas de 1650 y 1721. La reiteración de ésta última en 1795 nos adentra en el siglo XIX ${ }^{5}$.

Estas disposiciones legales apuntan una distinción entre lo que es propio del monarca y los limites de caza y pesca, una calificación de los "Sitios Reales con sus Palacios y Bosques, adquiridos por los Reyes a

F. Cos-Gayon, Historia juridica del Patrimonio Real. Madrid, 1881, págs. 95-96. Ordenanzas de 31 de mayo de 1795 para el Gobierno del Real Sitio de Aranjuez en Ordenanzas para el Goblerno del Real Sitio de Aranjuez. Madrid, 1795. Ed. fac. Aranjuez, 1989, Apéndice, págs. 1-99. Las Ordenanzas de 21 de enero de 1650 del Real Sitio de Aranjuez menguan considerablemente los limites de Felipe II y Felipe III. Esta nueva circunscripción es confirmada por Felipe $V$ por Real Célula de 21 de enero de 1721 de Limites. AGP. Planos, núm. 581. 1798. Plan de los terrazgos que comprende el Real Sitio de Aranjuez y de la extensión de los limites de la caza antiguos y nuevos /Juan Antonio Alvarez. 
título de compra, permuta, herencia u otro cualquiera de los ordinarios del derecho común" ". Además la propiedad del monarca sobre puentes, molinos, derechos impositivos permite hacer extensibles las demarcaciones del Real Sitio más allá de los propios limites físicos. Son, en el que se continúa llamando Real Heredamiento, intereses de carácter económico (aprovechamiento de maderas, agricultura) los que ahora, si no desplazar, al menos van a suponer una alternativa a la tradicional finalidad cinegética.

Más los jardines no se olvidan. Tres anillos, el urbano, el de los jardines y huertas, el de las grandes extensiones para cazar, conforman un espacio único, plenamente conformado en las puertas del siglo $x \mid X^{7}$.

\section{EL SIGLO XIX: PROCESOS DE DESINTEGRACION E INTEGRACIÓN}

\subsection{El inicio del siglo. Los últimos años de Carlos IV (1800-1808)}

La Cédula del Consejo de Castilla de 21 de octubre de 1800 decretando la desamortización de todo el Patrimonio Real anuncia la nueva centuria. Es el primer intento por inventariar el Patrimonio Real, entendido como Patrimonio a disposición del Monarca, que incluiría tanto las áreas reservadas como las de su propia pertenencia, a fin de vender las innecesarias. Carlos IV excluye solamente los Palacios y Sitios Reales. Ello obedece a esa distinción entre los Reales Sitios propiamente dichos, -en Aranjuez Palacios y Jardines-, y los terrenos reservados para caza, que Carlos IV considera como integrantes del Patrimonio Real, por esa asimilación en el tiempo, que confunde lo reservado con la propiedad de derecho. Este proceso de venta se interrumpe con los acontecimientos de $1808^{8}$.

\section{F. Cos-Gayon, Op. cit, págs. 88-89.}

Para el urbanismo del XVI-XvIII vid. "Cartografía histórica de Aranjuez", Riada. Estudios sobre Aranjuez, 3 (1991); A. BOnET CORREA, "El Real Sitio y Villa de Aranjuez en el siglo xvill: Arquitectura y urbanismo", El Real Sitio de Aranjuez y el Arte Cortesano. Madrid, 1987. Págs. 17-31.

"F. Cos-Gayon, Op. cit., pág. 131. Recordemos el Convenio de 5 de mayo de 1808 suscrito entre Napoleón y Carlos IV, por el que éste renuncia a su propiedad privada, pese a su indefinición respecto del Patrimonio de la Corona. Art. 9": "S.M. el rey Cários renuncia a favor de S.M. el Emperador, todos los bienes alodiales y particulares no pertenecientes á la corona de España, de su propiedad privada en aquel Reino". 


\subsection{La Guerra de la Independencia (1808-1814)}

En la órbita napoleónica, la Constitución de 6 de julio de 1808, promulgada por José Bonaparte es importante no sólo por las diferenciaciones que respecto del Patrimonio apunta, sino por suponer la primera enumeración de bienes con una estructura que será una constante en el siglo: palacios en principio, parques y bosques más adelante, cercados y otras propiedades; por último, diferenciación que se hará corresponder grosso modo, con los límites entre propiedades del rey, propiedades para uso y recreo del rey, propiedades del Estado ${ }^{9}$.

Mayor relevancia posee la actividad legislativa de las Cortes de Cádiz. En fechas previas a la Constitución de 1812 un Decreto de 22 de marzo de 1811 que no llegará a ejecutarse, pretende vender las fincas de la Corona de las que se exceptuarian "los Palacios, Cotos y Sitios Reales", es decir, las que no tenían carácter de Sitios Reales. De una forma u otra se comienzan a entender determinados bienes como no imprescindibles para el monarca, aunque no se precise por el momento si a título privado o como personificación de una Institución, la Corona.

La Constitución de 19 de marzo de 1812 o de Cádiz consolida como bienes intrínsecos e innegables a la Corona los Palacios, y desliga de la misma los grandes terrenos que se verá obligada a arrendar, salvo lo que sea "conveniente reservar para el recreo de su persona".

El inicio en la aplicación de la norma a partir de 1813 supone problemas. Por ello se decide excluir los bienes del Real Patrimonio de un Decreto de 6 de agosto de 1811 que abolía los privilegios exclusivos, privativos y prohibitivos. Esta exclusión será decisiva por perfilar ya un conjunto de bienes sobre los que más adelante se argumentará su reserva y protección, tanto por servir a la representación y protocolo del Rey y la Familia Real, como por garantizar la conservación de su valor histórico y artístico. El Decreto de 28 de marzo de 1814 vendrá a clarificar la Constitución de 1812. Para ello dispondrá las propiedades que, ya en manos del Estado, se reservan para uso y disfrute del rey ${ }^{10}$. Por

lbidem, pág. 130; F. Diez MORENo, "La evolución constitucional del Patrimonio Nacional", Reales Sitios, $n^{\circ}$ extraordinario (1989) pág. 17. Art. 21. Parece separarse ya el Patrimonio de la Corona de otro patrimonio cuyas dimensiones se adaptan a los limites de la Nación.

10 F. Diez Moreno, Op. cit., pág. 19. Art. 5: "los Palacios Reales, sitios, bosques, jardines, dehesas y demás terrenos del llamado Patrimonio Real". Art. 6: "La Regencia remitira inmediatamente a las Cortes todos los apeos, deslindes, amojonamientos y titulos de pertenencia de los Sitios Reales, Palacios, Alcázares, jardines, cotos, bosques, florestas, dehesas y terrenos perte. necientes hasta aqui al llamado Patrimonio del Rey... con los testamentos de los Sres. Reyes $D$. Felipe V, D. Fernando VI y D. Carlos $/ 1 /$. 
primera vez, se procederá a la elaboración de un inventario, o relación de bienes que intenta clarificar límites sobre el conjunto del Patrimonio. Los palacios serán reservados al Rey en calidad de representante de la institución monárquica.

\subsection{Fernando VII. Avances y retrocesos (1814-1833) "}

El Decreto de 22 de mayo de 1814 que restituye los limites del Patrimonio de la Corona a la situación anterior a 1808, supone la nulidad de la labor de las Cortes de Cádiz.

Será durante el Trienio Liberal cuando se proceda, por Reales Decretos de 28 de abril y 30 de mayo de 1820, a la segregación de fincas de los Reales Sitios, de aquellas que no fuesen adjudicadas al monarca para su recreo por las Cortes ${ }^{12}$ :

"Aranjuez y Jarama. Quedan reservados el Palacio, jardines, Casa del Labrador, cortijo, y los terrenos que se encuentran desde éste, linea recta á Bayona, y luégo rio abajo hasta el arroyo de D. Gonzalo, y siguiendo la línea por los cerros hasta el término de Ocaña á concluir en dicho cortijo, con las dehesas necesarias para la Real Yeguada... tambien las casas de oficio y aposento necesarias para las jornadas, y las que hayan de ocupar los empleados que Su Majestad conserve ${ }^{13}$,"

Se detallan los fines que justifican la reserva: los valores agrícolas y ganaderos de tipo experimental (se incluye el Cortijo y la Yeguada), los ámbitos plenamente regios que son los Palacios y las infraestructuras demandadas por las Jornadas y la Corte. A ello se suma un valor estético que justificaría la defensa de Aranjuez como lugar de recreo y singular ámbito natural "esta reserva se hace, no solo con el objeto de que sirva de recreo á S.M. sino con el de conservar el precioso arbolado de dicho Real Sitio". Entre las cesiones estarian los puentes y molinos (ya abolidos los derechos reales de molinos, abastos y pontazgos), las casas de la

\footnotetext{
F. Cos-Gayon, Op. cit., págs. 150-151, 155; F. Diez Moreno, Op. cit., pág. 19.

Propiedades a las que hacía referencia el Decreto de 28 de marzo de 1814 y el art. 214 de la Constitución de 1812.

is Según este Decreto, por el cual se procedia a la cesión de aquellas propiedades que no eran de uso del monarca, se establece el deslinde de fincas. Su valor radica en ser un claro inventario del Patrimonio Real en ese momento previo a la cesión. Decide el deslinde de las propiedades de Madrid, El Pardo, San Fernando, San Ildefonso, San Lorenzo, Sevilla, Granada, Valladolid y el transcrito de Aranjuez y Jarama.
} 
población, las acequias, y amplios territorios no dedicados a cultivos especializados: Villamejor y Mazarabuzaque ${ }^{14}$.

La Orden de 9 de agosto de 1820 reconocerá además al rey el derecho a ceder sus bienes, pero no a su reserva, que corresponde a las Cortes ${ }^{15}$. Mas el restablecimiento del régimen absolutista en 1823 sólo dejará en pie de la labor liberal la desaparición definitiva del fuero privativo y de los derechos señoriales ${ }^{16}$.

\subsection{El tercio central del siglo}

\subsubsection{El periodo $1838-1865$}

La muerte de Fernando VII en 1833 inicia un periodo de escasa actividad normativa, en el que sin embargo destaca la formación de las Comisiones de Deslinde de bienes, con el trasfondo de la actividad desamortizadora que ahora emprende Mendizábal y, ccn la creación de los ayuntamientos constitucionales, la irrupción del Aranjuez municipal.

\subsubsection{Las Comisiones de Deslinde}

Las fechas de 1838 y 1854 coinciden con las de creación de comisiones mixtas de deslinde. Uno de sus dictámenes remitidos al Ministerio de Hacienda relativo a Aranjuez, manifiesta cómo «el Patrimonio Real posee con legítimos títulos las fincas, dehesas, casas y demás que forman el

\footnotetext{
14 Un documento de 1824 (AGP. Administraciones Patrimoniales. Aranjuez. Lg. 65) examina para su reconstrucción, el estado de las propiedades de Aranjuez tras el Trienio Liberal. Los sucesos políticos que dieron paso al Trienio Liberal ocasionaron daños y destrozos (talas de árboles, pérdida de jardines, frentes, e invasión de los pastos de la Yeguada Real). Referencias encontramos también en F. Cos-Gayon, Op. cit., pág. 154.

F. Cos-Gayon, Op. cit., pág. 159. Esta decisión destaca esa reserva al Monarca como representante de la Cornona como institución. Aun asi el monarca intentó mantener intacto el Real Patrimonio, mediante la aportación de pruebas documentales sobre la legitimidad de la propiedad del rey.

F. Diez Moreno, Op. cit., pág. 20. El Decreto e 14 de junio de 1823 ordena la devolución de bienes que habian sido segregados conforme a lo ordenado en el Trieno I_iberal. El Decreto de 16 de julio de 1823 restablece el Fuero Privilegiado de los Bienes de la Corona, frente a la generalizada abolición de privilegios decretada en 1820. El Decreto de 16 de julio de 1823 restablece el Fuero Privilegiado de los Bienes de la Corona, frente a la generalizada abolición de privilegios decretada en 1820. El Decreto de 19 de noviembre de 1825 declara nulas las ventas realizadas entre 1820 y 1823 .
} 
Sitio o Heredamiento de Aranjuez" ${ }^{17}$. Con la acreditación documental que se solicitaba desde el Trienio Liberal, la Corona conservará integramente lo que había poseído con Carlos IV.

\subsubsection{Aranjuez Municipal}

La institución municipal surge con la creación de los Ayuntamientos Constitucionales en 1835. Desprovista de patrimonio inmueble, poco a poco, para el ejercicio de sus funciones irá logrando la cesión de fincas tanto urbanas como rústicas, que en un principio no son sino arrendamientos y alquileres que realiza el Patrimonio Real. Desde ahora el proceso de desintegración del Patrimonio Inmueble de la Corona se verá entrelazado con la historia del municipio. Aranjuez municipio, al no disponer de territorio, dependerá del Patrimonio Real o del Estado, según la alternancia de periodos monárquicos y republicanos, para establecer sus servicios.

A esta peculiaridad de Aranjuez achaca Simón Viñas su decadencia en un siglo en que la Monarquía pierde sus ancestrales privilegios y la sociedad democrática se va imponiendo:

"..el Real Sitio de Aranjuez fué regido por gobernadores que eran á la vez administradores del real Heredamiento hasta el año 1836. En este año se declaró pueblo y tuvo ayuntamiento separado de la administración lde la Corona], entrando en el régimen general gubernativo de los demás pueblos de la Nación, si bien arrastrando una vida lánguida municipal por no tener absolutamente bienes ningunos con que sostener sus cargas las cuales hubieron de pesar siempre sobre las especies de consumos, único arbitrio que ha tenido, por cuya razón la vida en Aranjuez ha sido y es más cara proporcionalmente que en otras poblaciones de su clase; pues como queda indicado, aunque módico tenia que pagar el arrendamiento de las casas consistoriales y demás edificios y fincas del servicio comunal'" ${ }^{\prime \prime}$.

"F. Cos-CAYON, Op. cit., pág. 162, 183. Estos dictámenes venían a solventar los problemas derivados de las ventas de 1820-1823 anuladas y las reclamaciones consiguientes de los compradores afectados una vez establecido el régimen constitucional. La propia Mayordomia Mayor pide al Ministerio de Hacienda el 16 de junio de 1838 la elaboración de un proyecto de ley a ele. var las Cortes para su aprobación con el fin de salvar estos problemas.

in Simon Vinas, maestro de Aranjuez testigo de los acontecimientos en el úlimo tercio del siglo, es el autor del epílogo de 1876 a la obra de Cándido López y Malta. S. VIÑAS, “Epílogo. Seis años despues". Historia Descriptiva del Real Sitio de Aranjuez escrita en 1868 por Cándido López y Malta sobre lo que escribio en 1804 D. Juan Alvarez de Quindós. Aranjuez, 1876, ed. fac. de la ed. de 1868. Aranjuez, 1988, págs. 514-515. 
La única fuente de ingresos se limita a los impuestos por consumo. Así la institución municipal reclama almacenes para abastos e inmuebles para la prestación de unos servicios que la Corte nunca exigió. Los establecidos con la nueva planta de la población de 1750 son insuficientes (Matadero) o inadecuados (Hospital ${ }^{19}$ ). Otros no existen: Cementerio (dependía de la parroquia de Ontigola), Casa Consistorial - se usará la Casa de Empleados-, Escuelas, Mercado. La solución provisional -arriendos o alquileres ${ }^{20}$ - evidencia una necesidad de espacios para la gestión de servicios que el Ayuntamiento comienza a asumir.

En conjunto nos situamos en una vigente, aún hoy, vinculación de los inmuebles de valor artístico - Palacios y Jardines- al Patrimonio de la Corona, de los más próximos al pueblo - los de servicios- al Ayuntamiento o al Estado. Entre estos bienes podemos incluir otros como la Plaza de Toros o el Teatro, así como los que denominamos obras públicas que si bien ahora es innegable su valor histórico artístico no era así bajo los criterios decimonónicos.

\subsubsection{Usos de los bienes que integran el Patrimonio Real}

Las relaciones del Patrimonio Real con la institución municipal no son las únicas. Semejantes procesos se producen respecto de todos los propietarios. En este sentido interpretamos la Circular sobre enajenación de fincas no vinculadas de 21 de marzo de $1849^{21}$.

En otro orden de cosas, relaciones e inventario de este periodo permiten determinar qué bienes posee el Patrimonio de la Corona, qué usos y valoraciones de los mismos se establecen. Con motivo de su restauración y mantenimiento, edificios y posesiones del Real Sitio son descritas en un Inventario de edificios y posesiones del Real Sitio en $1844^{22}$, que incluye una descripción de su estado de conservación y una propuesta de restauración realizadas por Narciso Pascual y Colomer, arquitecto de los Reales Sitios en ese momento ${ }^{23}$. Estos bienes seleccionados son: Jardín del Príncipe, Casa del Labrador, Real Cortijo, Jardín de la Isla, Real Palacio, Azuda de la Montaña, Casa de Marinos, Casa de Oficios. Se entienden como más urgentes las reparaciones sobre riegos y fontaneria

\footnotetext{
1: Ibidem, pág. 525. El Hospital de San Carlos convertido en granero, el Ayuntamiento intentara recuperarlo. Amadeo I lo abrirá como asilo.

AGP. Administraciones Patrimoniales. Aranjuez. C $C^{2}$ 14337, AMAj. C $1579 / 1$.

AGP. Administraciones Patrimoniales. Aranjuez. C 14369.

AGP. Administraciones Patrimoniales. Aranjuez. C 14360

AGP. Administraciones Patrimoniales. Expedientes personales. C ${ }^{a}$ 793/38.
} 
de la que dependen jardines y huertas, riqueza natural omnipresente en los elogios del Real Sitio. El texto ya insinúa el abandono, la carga económica del Real Sitio (pese a alquileres y arrendamientos de bienes urbanos y fincas rústicas -Deleite, Campo Flamenco ${ }^{24}$ - como fuente de ingresos), la dificultad de su mantenimiento ${ }^{25}$.

La Administración progresivamente diferencia propiedades y orienta sus usos: las rústicas hacia la agrícola y ganadera, las urbanas hacia la vivienda y los servicios. Se mantiene la explotación del bosque (venta de taray, viveros) y la caza ${ }^{26}$. Las ideas desamortizadoras se intuyen en Aranjuez, lo cual no implica que la Corona se vea dispuesta a ceder aquello que ahora bajo la fórmula del arrendamiento o similares está en otras manos ${ }^{27}$. Así los bienes evolucionan, si no en cuanto a la propiedad, sí respecto de sus usos, excepción hecha de los ámbitos estrictamente regios. En primer lugar, el grupo de terrenos rústicos, con las consiguientes modificaciones, de la caza a una utilidad agropecuaria (Sotomayor, Mazarabuzaque). En segundo lugar, los bienes inmuebles urbanos que, perdida su función vinculada a la Monarquía y la Corte, comienzan a orientarse hacia los nuevos usos del Estado, tanto a nivel de administración central como local.

\subsubsection{La Ley de 1865}

\subsubsection{La necesidad de una ley}

En visperas de la Ley de 1865 el conocido como Patrimonio de la Corona no es sino un mayorazgo. El «Patrimonio Real» - inalienabilidad,

24 AGP. Administraciones Patrimoniales. Aranjuez. Ca 14368. El ejemplo es de 1847. Otros ejemplos de arriendos tenemos en el Deleite en 1833 (AGP C 14319), Parador de las Cuatro Naciones (AGP Ig. 71), Huerta de San Pascual en 1851 (AGP Ca 14380).

* S. Viñas, Op. cit., pág. 505. Con carácter administrativo y en la búsqueda de rendimientos a las propiedades, un Estado General de las Casas de su Majestad de 1848 (AGP. Administraciones Patrimoniales. Aranjuez. $C^{\text {a }} 14368$ ) incluye también aquellas propiedades que no son de objeto estético y ornamental, sino funcional. Sin embargo con el paso del tiempo han adquirido los valores histórico y artístico de los que en el momento de su construcción adolecian. Se recogen datos como estado de conservación, estado de alquiler y rendimientos, gastos que ocasiona y el propio valor de cada uno de los inmuebles. El texto los denomina Casas del Rey y explicitamente deja al margen, como pendientes de tratar en otro lugar, aquellas que se presuponen claramente del rey y cuyo valor es elevado: Palacio Real, Real Parroquia de Alpajés, Convento de San Pascual, Convento de San Antonio. En esta relación de fincas urbanas, destaca la Casa de los Curas, Fruterias Nueva y Vieja, Fábrica de Vidrio, los Cuarteles (de Guardias Walonas Españolas y de Corps), la Cárcel, Alamacenes, Escuelas, Tahonas, Caballerizas, Teatro, Fábrica de Aguardiente, Matadero... Son propiedades próximas a servicios o a arquitectura industrial, a una arquitectura vinculada a lo doméstico y cotidiano. 
imprescriptibilidad, indivisibilidad-, en contradicción con procesos desamortizadores $(1836,1855)$ y supresión de señorios es una situación anómala tolerada porque se es consciente de la existencia y presencia de la Monarquía, pero también de la protección del cúmulo de riqueza histórica y artística que respalda la imagen de los monarcas y su familia. El propio vacío normativo desde la época de Fernando VII había contribuído a esta transmisión intacta del patrimonio a la subida al trono de Isabel II.

La Ley de 12 de mayo de 1865 vendrá por tanto a establecer la delimitación por vez primera del conjunto de bienes del Patrimonio de la Corona pero no de libre disposición del Monarca, y la continuación del proceso desamortizádor iniciado y paralizado en $1808^{28}$. Asimismo señala los trámites a ejecutar ${ }^{29} \mathrm{y}$ ordena la elaboración del inventario ${ }^{30}$ que permita la enajenación de los bienes excluídos, en las formas de donación, permuta, enfiteusis ${ }^{31}$.

AGP. Administraciones Patrimoniales. Aranjuez. C 14401 leg 104. El documento es de 1859. El plan de aprovechamiento de bosques de 1863-1864 (AGP. Adrninistraciones Patrimoniales. Aranjuez. C $\mathrm{C}^{\mathrm{a}}$ 14374) habla de esta forma de rentabilizar aunque mínimamente el Real Sitio.

La palabra desamortización sólo será usada por Almazán y Simón Viñas. Ejemplos al texto son: el cementerio, nuevo servicio que la Corona cede al Ayuntamiento, pero sólo su dominio útil (AMAj. C a $^{-507 / 8)}$ y la venta y enajenación perpetua a censo enfitéutico del Deleite, por la Reina Isabel II a su madre (AHPM. Protocolo na 26354. Escritura de 5 de diciembre de 1851).

: Para ello se creó nuevamente una Comisión Mixta Estado-Corona. Respecto de la ley nos remitiremos tanto al proyecto presentado por la Corona como al texto definitivo. $F$. Cos-CAYON, $O p$. cit., Apéndice, los recoge textualmente. F. DIEZ MORENo, Op. cit., pág. 21.

* También es recogido en el Proyecto de Ley. Este proceso de deslinde y ventas, se había intentado ejecutar en las fechas previas al reinado de Fernando VHl, retomar en el Trienio Liberal, y se habia perdido en 1823.

10 Art. $4^{ \pm}$de la Ley "detallado, existimativo y descriptivo de todos los bienes inmuebles, muebles y semovientes... comprendidos en los articulos $1^{2}$ y $2^{a}$ de esta ley" así como el levantamiento de "planos topográficos de todas las fincas rústicas del Patrimonio de la Corona". Estos planos serán fundamentales no sólo por ser los primeros, sino por servir de base a trabajos posteriores (p.e. Almazan Duque). El de Aranjuez, es levantado por la Junta de Estadistica entre 1865 y 1866. Ha sido reproducido en Cartografia..., núm. 7 .

Se respeta igualmente la posibilidad de arrendamiento asi como la facultad de ceder el dominio útil de solares para construcción de casas en el caso concreto de Aranjuez, en la forma en que se venia realizando pero durante un periodo que sólo podrá prolongarse durante 40 años más. F. Cos-Gayon. Op. cit., pág. 366. Art. 6. Esta cesión se venía realizando desde la creación de la población por Fernando VI en 1751 y su pareja prohibición de desvinculación de solares de 1757 (RO de 20 de agosto de 1757) Vid. Ordenanzas..., Apéndice, pág. 140-144. Tenernos noticia de su control en 1849, (AGP. Administraciones Patrimoniales. Aranjuez. C 14370 ), y de su ratificación en 1851: Real Orden de 23 de septiembre de 1851 complementada con las Reglas y prescripciones que se establecen y á las que deberán sujetarse todos los que adquieran terronos propios del Real Heredamiento de Aranjuez para edificar en el mismo aprobadas el 5 de mayo de 1852 (AGP. Administraciones Patrimoniales. Aranjuez. C $\mathrm{C}^{\mathrm{a}}$ 14370). En correspondencia gráfica hallamos el Plano de 12 de abril de 1852 de solares destinados a la edificación el Real Heredamiento de Aranjuez, según Orden de 23 de septiembre de 1851 (AGP. Planos. núm. 590), de tal forma que la expansión de la población de Aranjuez continuaria realizándose en la manera establecida dese un principio. Este sistema se mantendrá hasta 1905. 
En la enumeración de los bienes y derechos del Patrimonio de la Corona, se incluye el Real Sitio de Aranjuez, con sus pertenencias y yeguada ${ }^{32}$. Se excluyen bienes como los Cuarteles (de Guardia de Corps, de Guardias Españolas, de Guardias Walonas, El Pajarón ) y en general los predios rústicos y urbanos no recogidos expresamente ${ }^{33}$. El inventario de bienes, apoyado en el levantamiento de planos iniciado por la Junta General de Estadística recogerá aspectos técnicos (situación, medidas, linderos de fincas y edificios) y económicos (censos, cargas, servidumbres) ${ }^{34}$. Sin embargo, con excepción del citado plano, no conocemos documento que nos permita establecer los límites entre propiedades, ni las ventas realizadas. Por ahora sólo se fijan el Palacio y sus dependencias adscritos al rey, así como los cuarteles al Estado ${ }^{35}$.

\subsubsection{Repercusiones de la Ley de 1865 en Aranjuez}

En relación con los procesos desamortizadores la idea de utilidad pública, ya latente en el Proyecto de ley presentado por la Corona, señala como una de las funciones de la Comisión Mixta el determinar los edificios o terrenos del Real Patrimonio necesarios para los servicios públicos del Estado. Se pretende dar juego a edificios que ya habían perdido la función para la que se crearon (recordemos los Cuarteles ${ }^{36}$ ). Es la misma necesidad, ya apuntada, del municipio.

Otro punto de interés es el que afecta al mantenimiento del Patrimonio de la Corona. Se faculta al Rey para la alteración de tierras, parques, jardines, asi como remodelaciones, derribos, reparaciones de los Palacios y otros edificios, con la intencionalidad de conservación y embellecimiento.

32 Art. 13.6. Ello coincide con la enumeración que aparecía en el Proyecto de Ley presentado por la Corona. Se mantendrá hasta 1931, aunque no coincidirá exactamente debido al paréntesis 1868-1875, y pese a los esfuerzos de la Ley de 1876 por volver a la situación que ahora referimos.

3 Art. 3․ de la ley, no contemplado en el Proyecto de la Corona. F. DiEZ MORENO, Op. cit., pág. 21; F. COS-CaYon, Op. cit., pág. 299, 303.

${ }_{34}$ F. COS-CAYON, Op. cit., pág. 297-299. Obstáculos hallará la tasación de los bienes a enajenar, como la imposible valoración del arbolado En el AGP y AMAj. hemos encontrado relaciones parciales de épocas diversas que pueden coincidir con este esquema de inventario. Para Aranjuez en su medida, se presentaba la dificultad añadida de un empleo distinto en sus sistemas según los marcos de Madrid, Toledo y Alcalá.

35. Con la Ley de 6 de junio de 1869 se procede a la extinción del Patrimonio de la Corona y a la enajenación de sus bienes, con escasas excepciones, tomando como punto de partida e! mapa resultante de la Ley de 1865.

3i En estos momentos el Ejército se vincula a un Ministerio, no directamente a la Corona, de ahi suponemos la conveniencia del paso de su propiedad al Estado. 
En el espíritu del proceso de fragmentación del Real Patrimonio se pretende preservar en todo momento los valores artísticos e históricos, que alcanzan a lo que hoy llamaríamos ecológicos: el goce y custodia del arbolado corresponde al rey, pero la conservación, cotas y calas se atiene a la normativa estatal sobre montes.

Por otra parte, la Ley de 1865 supone la primera garantía de que los Museos y monumentos artísticos se conservan para el Estado, aunque vinculados al Patrimonio de la Corona. Son intenciones de cierto carácter cultural, simultáneo al uso y disfrute de la Corona, donde funciones de representación y culturales conviven.

Existe una voluntad de protección de bienes, pero desde las perspectivas desamortizadoras el cambio de propiedad implica el cambio del uso del bien desamortizado ${ }^{37}$. Detrás de la ley se halla la penuria del Tesoro y el freno a las pérdidas que ocasionan al Real Sitio "los terrenos cultivables en éste Real Sitio; por que á pesar de sus pingües producciones era un gravamen para la Corona, pues que muchos años tenían que venir caudales para sostener sus gastos" mediante unos mecanismos que garanticen cierta rentabilidad ${ }^{38}$. Recordemos cómo el Patrimonio Real habia dejado de ser productivo a partir de 1835, pero también cómo sus gastos se compensaban con sus ingresos, situación mantenida hasta 1868:

". .la renta (...) era consumida por los gastos de entretenimiento del Palacio, de los jardines, de los paseos y de la yeguada. Hoy todo lo que era productivo en Aranjuez ha sido vendido, y queda únicamente á la Casa Real la obligación de sostener un número grande de costosos edificios, la obligación de sostener vastos jardines(...) los magnificos arbolados (...) además de limpiar las calles donde están colocados. De manera que hoy Aranjuez es una finca gravosisima para el Patrimonio“" ${ }^{39}$.

\subsection{El sexenio democrático}

\subsubsection{L.os primeros momentos y la Ley de 18 de diciembre de 1869}

El periodo que antecede a la Ley de 18 de diciembre de 1869 es perjudicial para Aranjuez.Entre las causas la reducción de personal en el

\footnotetext{
i7 Quedarán provisionalmente exceptuados los bienes que habia cedido el Rey a particulares para construir terrenos bajo la tórmula del dominio útil.

3. S. VINAS, Op. cit., pág. 505.

: Cos-Cayon, Op. cit., pág. 325, 348.
} 
mantenimiento de los bienes, la llegada de trenes recreo en la primavera de 1869, la creación de merenderos, la aparición de los primeros domingueros y turistas, fenómeno que tiene su origen en el XIX paralelo al proceso de desarrollo de las clases medias, que comienzan a acceder a pequeños lujos y divertimentos que antes no conocian. Los mayores daños se producen en los jardines, que los ciudadanos "convirtieron en merenderos regando con agua de Valdepeñas las rosas y claveles... ". La nueva ley frenará la situación "se remediaron algunos males, para otros la medicina llegó tarde» ${ }^{40}$.

2.5.1.1. Los límites entre los bienes reservados al monarca y los bienes enajenables

La nueva "Ley declarando extinguido el Patrimonio de la Corona y de reversión al Estado, en pleno dominio, de sus bienes y derechos y los de la Real Casa, y disponiendo su enajenación" de 18 de diciembre de 1869 , permite que los bienes del ahora llamado Patrimonio que fue de la Corona, sean absorbidos tanto en dominio útil como directo por el Patrimonio del Estado, reservando una parte al uso o servicio del rey, con independencia de su reconocido Patrimonio Privado, y procediendo a la enajenación del resto, "la mayor parte del área del Real Heredamiento de Aranjuez". Es decir, se reservan al monarca Palacio y jardines, tandem antiguo. Los bienes para uso y servicio del Rey son "el Palacio de Aranjuez con los edificios anejos á su dependencia para caballerizas y aposentamiento, y en el mismo Sitio los jardines denominados Parterre, de la Isla, del Príncipe con la Casa del Labrador, y el área que comprende las 12 calles de árboles que forman los paseos y las transversales $y$ accesorias á estos" ${ }^{41}$.

Se entiende por dependencias de Palacio: Patio Cuadrado, Casa de Oficios, la Regalada, edificios al servicio de los empleados y anteriores a la planificación de la población de 1750 . El resto de las fincas urbanas se enajena incluido sorprendentemente el propio Jardín de

4. S. VIÑAS, Op. cit., päg. 499.

${ }^{41}$ F. Cos-Gayon, Op. cit., pág. 370 ss. Para los bienes reservados se conserva la Administración directa por parte de la Corona así como los privilegios consiguientes de exención de impuestos y contribuciones. Se procede a la enajenación del resto de los bienes excepción hecha de los que merezcan conservarse por su interés histórico y/o artístico (art. $2^{\circ}$ Segundo), los que puedan utilizarse en servicios del Estado (art. $2^{\circ}$ Tercero) y, novedosa salvedad, los que sean susceptibles de cederse para servidumbre o usos públicos de los municipios reconocidos desde 1835 en los Sitios Reales (art. $2^{\circ}$ Cuarto). 
Isabel II ${ }^{42}$, mediante pública subasta conforme a las leyes desamortizadoras ${ }^{43}$.

\subsubsection{La ejecución de la ley. La formación del inventario de fincas rústicas y urbanas}

Los Archivos General de Palacio y Municipal de Aranjuez testimonian la materialización de los esfuerzos teóricos del XIX. Son los primeros inventarios y relaciones de los bienes de la Corona clasificados con el modelo de inventario ya definido en 1865. Una "Relación de los bienes que constituyen el Patrimonio que fue de la Corona, con expresión de los arrendados y vacantes", fechada en 15 de abril de 1869, nos muestra el estado de las propiedades rústicas que ahora pretenden enajenarse. Las huertas aparecen arrendadas en su práctica totalidad ${ }^{44}$.

Un Inventario General del Real Heredamiento de 1869 dedicará su undécima sección a Aranjuez, "con sus dependencias y la Yeguada existente en el mismo", relación a completar con la información detallada de cada bien ${ }^{45}$. Otras propiedades (Puente Colgante y carretera) serán entregadas al Ministerio de Fomento, suponemos que en calidad de bienes de uso público ${ }^{46}$.

A efectos administrativos, todas estas definiciones tienen presente una nueva división vigente desde 1867, momento en el que se extingue la Administración del Jarama y se anexiona al Heredamiento de Aranjuez: son "las 19.043 hectáreas del término municipal de Aranjuez, constitutivas há poco de este Patrimonio..." ${ }^{47}$.

4: S. VIÑAS, Op. cit., pág. 500. También aludirá a los problemas surgidos en torno al tema del área de las Doce Calles.

*: F. DIEZ MORENO, Op. cit, pág. 22. "Se ordena la redención o venta de toda clase de censos, capital, canon o renta, asi como los bienes de los Reales Patronatos". Plasmado en la normativa de 1865 el proceso ahora es de mayor repercusión.

4 AMAj. C $507 / 5$. Fincas: Tejeras, Doce Calles, Cabezadas, Flamenca, Casa de Serranos, Mazarabuzaque, Contijo, Deleite, Huerta de Secano (con alguna vacante), Acequia de Tajo (vacante casi toda), Sotogordo, Soto del Espino, Cortado de la Herradura, Molinos y Venta de Aceca, Pozos de la Nieve y Pastos (Titulcia, Puente Largo, Miralrey, Regajal, Castillejo, Villamejor, Mazarabuzaque), Yeserias

45 AGP. Administraciones Patrimoniales. Aranjuez. C $C^{\text {a }}$ 14422. La cuestión de la Real Yeguada se retomará con Amadeo I. Su inclusión en este inventario coincide con la referencia explícita de la Ley, inclusión tradicional desde el Decreto de 30 de mayo de 1820.

46 AGP. Administraciones Patrimoniales. Aranjuez. C 14425 . Serán objeto de disputa en años venideros entre Patrimonio, Estado, Municipio.

47 J. AlmazÁn DuOUe, Enajenación del Patrimonio de Aranjuez. Informe. Madrid, 1870, pág. 12. 


\subsubsection{Criterios de enajenación. La iniciativa de Almazán Duque}

La forma de enajenación de los bienes de la Corona será similar a la que Madoz adopta respecto de bienes ya no exclusivamente eclesiásticos, sino de espacios, por primera vez, que estaban en manos del Estado ${ }^{48}$. Las iniciativas se encomiendan al Ingeniero de Obras Hidráulicas José Almazán Duque, quien buscará unas mejores distribución de la propiedad y explotación de recursos, entendiendo la desamortización como forma de fomento de la riqueza pública ${ }^{49}$.

1. La clasificación de los bienes rústicos: regadio, susceptibles de regadio y secano.

Los terrenos de regadío, enajenables, desea pasen a la pequeña propiedad, apreciando las ventajas de habitar sobre la heredad que se cultiva "!Cuánto queda, por fortuna, de biblico y de patriarcal en esa vida y en esas costumbres tan primitivas!", evocación idílica de los orígenes del hombre que los avances de la civilización van deteriorando. Almazán propone convertir en propietarios a los colonos "en armonía con el interés general del Estado, vender aqui á la vez los muchos edificios que posee el Patrimonio y no se reservan al Monarca" con la intención de que llegue "el pueblo á adquirir vida propia» ${ }^{50}$ con esa concepción decimonónica de nuevas ciudades incardinadas en la naturaleza...

Las tierras de secano susceptibles de riego, el Estado las convertiría en regadio para proceder a su enajenación posteriormente ${ }^{51}$. Por último, los terrenos de secano se aprovecharían como "pastos naturales, plantaciones de viñas, ó siembra de cereales", cultivos extensivos. La reserva de dehesas y dependencias necesarias para la yeguada ${ }^{52}$ permitirá que «el suntuoso edificio de Sotomayor, erigido á propósito para la monta, la vega

4h “Art. 8․ Se consideran como censos para los efectos de esta ley los arrendamientos comprendidos en el art. $2^{\circ}$ de la Ley de 27 de Febrero de 1856, aclaratoria de la desamortización de $1^{\circ}$ de mayo de 1855 ".

49 AGP. Administraciones Patrimoniales. Aranjuez. Ca 14431. J. AlmazAN DuQUe, Op. cit., págs. 5,6 .

so Ibidem, pág. 111-118. Sitúa el regadio "desde la Junta de caces por el Este, hasta las Infantas por el Oeste, se encierra toda la zona cultivada".

t1 lbidem, pág. 124-128. "desde Pajares en Jarama y desde Valdajos en el Tajo y á la izquierda del Tajo de Sotomayor á Toledo".

: Ibidem, pág. 141-142. La falta de deslinde y amojonamiento es un grave problema. Se sugiere la rectificación y revisión del deslinde practicado en 1833 especialmente respecto del coto redondo de Aranjuez. El trabajo de la Junta de Estadistica será el único fiable en ei momento. 
y aitos accesorios, las Potreras de Badino, el prado de la Cabina y alguna otra" "53, mantengan los usos para los que se crearon.

2. Almazán y los bienes reservados al monarca ${ }^{54}$.

Ante la escasa colaboración de la administración patrimonial en la prosperidad de la comarca y mediante la crítica de los privilegios de la Corona, Almazán entiende como positivo "en una Monarquía democrática... dedicar una muy pequeña parte, á la conservación de joyas nacionales tan preciadas como los palacios, jardines y arboledas de Aranjuez" La ley de desvinculación del Patrimonio, como Almazán la llama, establece una consignación directa al Monarca, la enajenación de todas las fincas productivás, "de esos bienes destinados á un fausto inútil» y la asignación de palacios, jardines, parques "y sitios análogos de recreo", que no implican renta o beneficio (todo sin perjuicio de su patrimonio privado).

Pero también se busca el difrute de estas propiedades excepcionales por parte de la población de Aranjuez, de la población española, proponiendo la no enajenación de árboles y su consideración "como de uso publico, al cuidado del municipio las que no se reserven al Monarca". Valores estéticos y funcionales respaldan la idea de utilidad pública. El Estado, a través de Ministerios o de la Dirección del Patrimonio "que fue de la Corona" iniciará la venta de bienes proyectada, aunque no sin dificultades. La desamortización, planteada sobre los bienes correctos, no encontró los compradores adecuados. Los modestos arrendatarios y jornaleros nunca se convirtieron en propietarios, porque la tierra que trabajaban sólo era accesible a elevadas fortunas.

\subsubsection{Amadeo de Saboya: la reclamación de propiedades}

En 1871 comienzan a sucederse reclamaciones de fincas entre Estado y Patrimonio. Un "expediente en que se declara la necesidad de reservar al Monarca varios terrenos y edificios enajenables" conforme a !a ley de 1869, reclama la Casa Frutería (como anejo de los jardines), los Pastos necesarios para la Real Yeguada - se excluiria Sotomayor de la venta-, la Oficina de Farmacia en la calle del Capitán, la Casa de Mulas y el

\footnotetext{
53 Ibidem, pág. 142. Edificios vinculados a los experimentos y ensayos en tomo a la ganaderia y agricultura del siglo XVIII: (Cortijo de San Isidro, Casa de Vacas, Potreras de Badino, la Flamenca, las Infantas) deberian convertirse en el núcleo de haciendas especiales y nuevas poblaciones.

s4 Ibidem, pág. 119, 121, 143.
} 
Hospital de San Carlos, recuperado nuevamente para su función ${ }^{55}$. Todo un conjunto de edificios que por sus funciones el Estado habia considerado innecesarios para el servicio del Monarca, en su práctica totalidad podrán recuperarse, debido a la citada dificultad en la venta de bienes por parte del Estado.

El Acta Notarial de 19 de julio de 1871 de entrega de bienes al Monarca ${ }^{56}$ constituye la consolidación de este expediente recién revisado que indica la reserva al rey. Tras dibujar el perimetro que encierra los bienes del Real Patrimonio, pasa a detallarlos:

Las que dentro del perímetro trazado pertenecen al patrimonio de $S$. $M$ : son las siguientes-EI Palacio con sus plazas y calles adyacentes-los edificios Patio Cuadrado y de Oficio-Casa de Infantes-Capilla de San Antonio-El Picadero-Los Fogones-La Fruteria-La Caballeriza llamada La Regalada-La Casa de Mulas en que hoy están los ganados de labor. El que se conoce con el nombre de cochera, situado en la fuente de Abastos y calle del Capitán-La Casa del Labrador cita llamada en el Jardin llamado del PríncipeLa Casa de Vacas cita en las doce calles y el Hospital de San Carlos enclavado en esta población.

Las fincas rústicas comprende todos los jardines, incluso el titulado hoy de Serrano con sus caceras y cuantas obras de Artes encierra y las llamadas el Rebollo-Viveros-Parque de Miraflores-El Depósito de árboles de la derecha de la calle de la Reina-El Pinarcillo-Las Potreras-Tranzones de las Doce Calles-Tranzones de las Tejeras-Madre del Moledor y Jaramilla-Mesa del Cebo-Huertas de Picotajo-Legamarejo-Raso de la Estrella y cuantas fincas en fin estan dentro del perimetro descrito, salvo de lo que resulte de las reclamaciones incoadas respecto á algunas que han sido vendidas...

Quedan asi mismo dentro las aguas potables... fuentes... la presa llamada del Embocador de la cual se derivan las acequias de la Zuda-y de las Aves, las aguas de estas salvo las concordadas que respecto de la conservación de las obras hidráulicas, de la distribución y régimen de aprovechamiento han de hacerse entre la Real Casa y los actuales usuarios ... de las fincas de regadio (...)

El Acta, un convenio entre la Dirección de Propiedades y la del Patrimonio, cumple en parte las peticiones: Hospital, Cocheras, Casa Mulas, Picadero, Fogones, Frutería y media casa de Infantes (procedente

s. AGP. Administraciones Patrimoniales. Aranjuez. C ${ }^{\text {a }}$ 14431. La Farmacia tendemos a identificarla con el actual Casino. El Hospital construido para aterider a empleados y vecinos de Aranjuez, habia conocido relevantes remodelaciones con Isabel li de la mano de José Segundo cie Lema.

si AMAj. Ca 507/9. El texto integro ha sido localizado en AHPM. Protocoto n 29965. Documentos gráficos de la época refleịan los limites: AGP. Planos. núm. 2468 y 2469 . El primero ha sido reproducido en "Cartografía...", núm. 8. 
del secuestro de propiedades del Infante Don Carlos -recordemos el conflicto carlista-) entre las fincas situadas en el casco. Otras (Dehesa de Sotomayor, calles de arbolado) quedarán bajo la Administración de la Real Casa mientras se resuelven las reclamaciones.

Posteriores son una Relación de fincas rústicas y urbanas de 27 de julio de $1871^{57}$ del Patrimonio y un Estado de 4 de noviembre de 1871 suscrito por Fabriciano López Rodríguez, que recogen una precisa toponimia, así como la extensión de algunas fincas ${ }^{58}$.

\subsubsection{La Primera República (1873-1874)}

Con la abdicación de Amadeo I, la Primera República intentará una vez más la enajenación y subasta de fincas que por convenio entre las direcciones de Propiedades y del Real Patrimonio se habian reservado al rey. La Ley de 24 de julio de 1873 dispone la incautación de bienes que habían pertenecido al Patrimonio de la Corona y que ahora pasan al Estado. Su administración dependerá de la Presidencia de la República hasta el momento de la llegada de Alfonso XII.

Se enajena todo, salvo el "soto de Legamarejo, soto del Rebollo, parque de Miraflores, Sotomayor, Hospital de San Carlos, casa de Infantes, casa-cocheras de la Reina Madre y la mitad de la de los fogones", el viaje de aguas desde Ocaña y el Mar de Ontígola, necesarios para el mantenimiento de los jardines. El proceso de venta se frenará en 1874 por el Real Patrimonio.

\subsubsection{Aranjuez muricipal durante el sexenio democrático}

Paralelamente al proceso de Desamortización de la Corona, el Ayuntamiento se plantea la adquisición de los bienes inmuebles que le son necesarios.

\footnotetext{
AGP. Administraciones Patrimoniales. Aranjuez. Ca 14433, leg. 120.

it Director del Real Patrimonio, quien firmaba también el Expediente sobre reserva de bienes al monarca examinado lineas atrás y la Relación de 27 de juilo. En esta relación de noviembre, respecto de la de julio aparecen nuevas fincas, asi como pormenorizadas las calles de árboles. Además reseña las propiedades del Acta de 19 de julio de 1871. La relación de ncviembre responde a la Orden de la Dirección General de Patrimonio de 27 de septiembre de 1871 sobre elaboracion de inventario de fincas rusticas y urbanas, de la totalidad del Patrimonio (AGP. Administraciones Patrimoniales. Aranjuez. $C^{\text {a }}$ 14432). De este momento son un conjunto de planos que hemos localizado en el Archivo General de Palacio (AGP. Administraciones Patrimoniales. Aranjuez. C 14432). Uno, reproducido en "Cartografia...", Plano núm. 7 , es el primero levantado con los limites precisos. Otros son los correspondientes a la Relación de noviembre de 1871 (vid. nota núm. 56).
} 
Para Almazán, una forma de sacar adelante el municipio, cuya propiedad está ahora en manos de la Nación, situación que él denomina anómala, es la «equitativa y graciosa concesión al municipio, en plena y absoluta propiedad, de la casa consistorial, de las aguas potables, y de algún paseo donde esparcirse el vecindario; con aquellas otras dependencias de cárcel, escuelas, matadero, etc., que todo pueblo ya constituido ha menester, $y$ de que Aranjuez carece por completo"... Es al propio Viñas a quien se encargará la gestión de "aquellos [bienes] que se cedan para las servidumbres públicas y usos comunes de los pueblos enclavados en los territorios que fueron de la Corona", bienes que revierten en pleno dominio al Estado, recogidos por la Ley de 18 de diciembre de $1869^{59}$, y cuya cesión al municipio tipifica la Ley de 9 de junio de 1869.

Simón Viñas evoca trámites y gestiones para la «adquisición de edificios propios para casas consistoriales, escuelas, depósito municipal, camposanto y matadero; pues nada de esto poseia la población». Exige “las fincas que, propias del Real Patrimonio, estaban anteriormente á ellos destinadas excepto para las escuelas que no habiendo locales antiguos más que para dos y existiendo cuatro, se pidió el edificio denominado Parador del Rey, para establecerlas todas en el mismo". Hubo que esperar hasta junio de 1873 para recibir del Estado estas propiedades aunque nuevamente en usufructo, las mismas arrendadas y alquiladas con anterioridad por el Real Patrimonio, excepto las Escuelas que finalmente se ubicarán en la Casa Administración del Real Patrimonio (la Casa del Gobernador que proyectase Juan de Villanueva a principios de siglo ${ }^{60}$ ).

Es también el momento en que el Alcalde, Pedro Maján, decide efectuar una división administrativa municipal en casco, radio y extrarradio. Son los limites de Aranjuez como término, respecto de otros municipios, no respecto de los propietarios que se yuxtaponen en él ${ }^{\natural 1}$.

\subsubsection{Repercusiones del sexenio democrático}

Los nuevos conceptos suponen algo más que el simple cambio de titularidad sobre los bienes inmuebles. Relevantes edificios del casco urbano

si J. Almazán Duque, Op. cit., pág. 118; S. Vinas, Op. cit., pág. 509

iw Ordenanzas... pág. 50. Esta cesión anima al Ayuntamiento a iniciar obras de acondicionamiento que afectan al Matadero, las Escuelas v el cementerio (S. VIÑA.S, Op. cit., pág. 511-512). Páráa el Mercado ya se había solicitado un terreno en 1854 (AGP. Administraciones Patrimoniales. Aranjuez. C 14387 ), pero su construcción sólo será posible en la década de los 90 por motivos económicos.

i) $v i d$. nota núm. 56. 
de Aranjuez, de difícil venta por su propia naturaleza y valor, en 1876 revierten con facilidad al Patrimonio Real, aun planteada y promovida su enajenación: son el Convento de San Pascual, Las Cocheras, la Plaza de Toros y el Teatro.

En general, y respecto de las fincas rústicas, la posibilidad de que el colono se hiciese propietario sería motivo para arraigar a la población «con la desamortización, las familias tendrán lazos que las una al suelo en que viven" "62. Viñas señala esta desamortización como conveniente aunque, consciente del momento en que escribe sus palabras - 1876 -, reivindica el protagonismo que la Corona no tuvo "...hecha la desamortización por el Monarca... para la localidad hubiera sido mas ventajosa quedando á salvo todas las bellezas de este Real Sitio y concertando las conveniencias de los adquirientes con las de la Corona". Así en otro momento parecerá contradecirse en la defensa de unos valores estéticos que la desamortización perjudicó: “desgraciadamente las primeras disposiciones han afectado á la hermosura de este Sitio Real, cuya conservación interesa á todos considerado como gloria nacionals, ${ }^{63}$.

$Y$ es que estamos en un momento en que Aranjuez se ha convertido en un lugar de moda, ya no exclusivo de la nobleza y monarquía, para esa pujante burguesía asentada en Madrid y que hace sus escapadas en busca de la naturaleza sin perder de vista su significado en las primaveras del siglo XIX: "es el rendez vous de la elegancia madrileña en la referida estación» ${ }^{64}$. Ahora se comienza a tener conciencia de que la propiedad regia es propiedad de todos, se puede disfrutar, aunque al monarca se le reserve para su uso. La visita a los Jardines comienza a ser masiva.

Mas el deseo de preservar el Real Sitio desde criterios históricos, artísticos y paisajisticos había ido en detrimento de esa renovación que para Aranjuez se pretende, aunque en ocasiones se hubiese culpado de este estancamiento al carácter variopinto y origen heterogéneo de la población, y su escaso amor y vinculo por y con el lugar. De hecho no se asientan industrias, es más, se rechazan las propuestas. La histórica vinculación de Aranjuez al ferrocarril estuvo a punto de no suceder. No pocas fueron las trabas a superar hasta su inauguración. Talleres y actividades vinculadas al nuevo medio de transporte se rechazaron por considerarse entorpecedoras para el propio esplendor de la Corona, la Corte, las Jornadas, que

S. VINAs, Op. cit., págs. 496-497, 506-507; F. Cos-Gayon. Op. cit., pág. 348.

(i) S. VINAS, Op. cit., págs. 504, 506.

14 AGP. Administraciones Patrimoniales. Aranjuez. $C^{a}$ 14432. En la época de isabel ll ya se abrian aigunos dias los jardines a los visitantes. 
no sacaron más partido del ferrocarril que el de conectar en menos tiempo la capital con las mismas puertas del Palacio ${ }^{65}$.

Almazán ${ }^{66}$ añadirá otra opinión, en absoluto contradictoria. Recuerda los orígenes del Real Sitio en el fomento del bosque y el de la caza. "la caza y ganadería mal entendida, han sido el dogal económico de Aranjuez". Critica las explotaciones de bosques realizadas en el periodo anterior "abandonar de propósito al.taray y á los matorrales la comarca más fértil del centro de España..sacrificándolo todo á la propagación de ciervos y jabalíes, lamentable error fué, que tres siglos y medio no han modificado en lo más mínimo" y denuncia los daños de la caza en la riqueza y expansión de Aranjuez. Pese a esta constatación, la enajenación ni se producirá a gran escala, ni pondrá la tierra en manos de los colonos, sino de una burguesía raramente del municipio, en su mayor parte madrileña ${ }^{67}$.

\subsection{La restauración 1875-1931}

\subsubsection{Alfonso XII 1875-1885}

2.6.1.1. El patrimonio de la Corona. Las leyes de 1876

Alfonso XII intenta hacer reversibles las actuaciones ya ejecutadas, recuperar los antiguos limites del Real Sitio. Las Leyes de 26 de junio de 1876 devuelven a la Casa Real todo lo que había quedado como integrante del Patrimonio de la Corona en $1865^{68}$. Varias fincas -rústicas fundamentalmente- nunca podrá recuperarlas, tampoco lo dedicado a servicios públicos. Aranjuez como municipio gozó del uso de algunos de estos inmuebles, pero sin alcanzar de la propiedad.

Con anterioridad a dichas leyes se habian sucedido reclamaciones de bienes del Patrimonio de la Corona al Estado e inventarios que cristalizarían en las Actas de entrega de 1876. En 1875 se reclaman fincas como la casa

is S. VIÑAS, Op. cit., pág. 506-507. Para el ferrocarril en España M. ARTOLA et al., Los ferrocarriles en España 1844-1943. Madrid, 1978.

iii J. AlmaZÁn DUQUe, Op. cit., pág. 31-32.

A modo de ejemplo AMAj. L 1101. 1894. Indice Alfabético de los propietarios comprendidos en el Registro Fiscal de Edificios y Solares según el art. 178 del Reglamento de 24 de enero de 1894. La mayoría de la propiedad está en manos de vecinos de Madrid, cuando no es del Estado o del Patrimonio. El habitante de Aranjuez dificilmente será propietario.

i. F. Cos-Gayon, Op. cit., pág. 332-333. Para el articulado de las Leyes de 1876 /d., Apéndice. 
de la Botica y el Hospital de San Carlos o la Dehesa de Valdelascasas. De hecho se recuperan el Hospital de San Carlos y la Iglesia de San Antonio ${ }^{69}$.

En el mismo año de 1875 (10 de abril) encontramos un Inventario ${ }^{70} \mathrm{y}$ una Relación de bienes a devolver, por el Estado al monarca. Entre los inmuebles se citan algunos no reseñados antes: Real Yeguada, Caces, Jardines, Casa del Ataud, Cocheras, Caballerizas, Oficios, Teatro, Fogones, Regalada, Casa de Infantes, Palacio, Casa del Labrador, Oficinas, Casas de Carruajes.

Así el Estado, por Decreto, entregará los bienes destinados al uso y servicio del Rey "1:

«el Palacio de Aranjuez con los edificios anejos á su dependencia para caballerizas y aposentamiento,... los jardines denominados Parterre, de la Isla, del Principe con la Casa del Labrador y el área que comprende las doce calles de árboles que forman los paseos y las transversales y accesorias a éstas"

Esta entrega al Real Patrimonio se irá completando en 1876 mediante sucesivas actas notariales, relaciones e inventarios de bienes ${ }^{72}$.

\subsubsection{Aranjuez municipal}

Los documentos de este momento insisten en la petición al Real Patrimonio de la cesión ratificada de los bienes inmuebles que venía utilizando el Ayuntamiento desde 1836.

El Ayuntamiento recibirá mediante la fórmula del usufructo ciertas propiedades, como la Plaza de Toros y el Teatro, cedidos por el Real Patrimonio que acaba de recuperarlos del Estado ${ }^{73}$. La explotación la ges-

69 AGP. Administraciones Patrimoniales. Aranjuez. C $C^{a} 14413, C^{a} 14441 ;$ AHPM. Protocolo $n^{\circ}$ 36723, $\mathrm{n}^{\circ} 76$. Acta de entrega de 1876.

1071 AGP. Administraciones Patrimoniales. Aranjuez. Ca 14441.

7. AHPM. Protocolo $n^{\circ} 36723, n^{0} 79$. Así la Dirección General de Propiedades y Derechos del Estado hace entrega a la Administración del Real Patrimonio de las propiedades solicitadas por la Intendencia General de la Real Casa, y que estaban "en poder del Estado". Citemos la Plaza de toros, el Teatro y el Palacio de Baviera. Entre las rústicas Sotomayor, Jembleque, Caz de las Aves, las calles de árboles, la Acequia del Jarama o Ciempozuelos, el Puente de Aceca, Soto Redondo, la Real Acequia de Tajo o de Colmenar de Oreja, la Barca de Requena. Quedan pendientes el Soto Rebollo, Legamarejo, tranzones y San Pascual.

i3 C. LOPEZ y MALTA, Op. cit., pág. 257-258; AGP. Administraciones Patrimoniales. Aranjuez $\mathrm{C}^{\mathrm{a}}$ 14491 y 14448 . Anteriormente con Isabel II se habia arrendado su explotación a particulares, el ejemplo más conocido es el de la Plaza de Toros al Marqués de Salamanca en 1851 (AGP. Administraciones Patrimoniales. Aranjuez. C $14379 \mathrm{lg} .96$ ). 
tiona el Ayuntamiento, que desde ahora será quien se encargue del arrendamiento a particulares ${ }^{74}$ y del mantenimiento de los edificios ${ }^{75}$. Las referencias al mal estado del Teatro y Plaza de Toros en los documentos (coincidentes con las citas de Simón Viñas) no son sino una muestra del grado de deterioro que va adquiriendo el Real Sitio.

\subsubsection{El nuevo mapa}

Las "Relaciones de las fincas rústicas y urbanas que pertenecieron al Real Patrimonio de Aranjuez" ${ }^{76}$ ) fechadas en Aranjuez a 7 de julio de 1876 y elaboradas por la Administración del Real Sitio de Aranjuez, nos permite identificar a los distintos propietarios de las fincas que antes de su deslinde y enajenación constituían un todo en vísperas de la Ley de 1865.

La primera de las relaciones señala aquellas propiedades que a juicio de la Real Casa pertenecian a la reserva del Rey y no obstante se vendieron. Asi el Picadero pierde su uso y pasa a convertirse en oficina del Real Palacio. También se había vendido la mitad de la Casa de los Fogones. Entre las fincas rústicas la Administración del Real Sitio incluye los conocidos Tranzones de las Doce Calles, frente a la Ley de 1869, que los considera enajenables.

La segunda incluye las fincas "que tiene el Ayuntamiento de la propiedad del Patrimonio de la Corona destinadas a servicios públicos, en virtud de concesiones hechas al efecto por el Gobierno": Casa de Empleados (para Casa Ayuntamiento), Casa Administración (para escuelas), Infantas 12 (Cárcel), Matadero y Cementerio de Santa Isabel. Como novedad en esta cesión al Ayuntamiento se incluyen como fincas rústicas «todas las calles arboladas dentro del casco de la población con inclusión de la Plaza de San Antonio y sus fuentes, la una monumental". Esta cesión dará lugar a conflictos de intereses entre Patrimonio y Ayuntamiento.

14 AGP. Administraciones Patrimoniales. Aranjuez. C" 14491. «.. la municipalidad..., solicitando que al ser devueltos al Real Patrimonio los edificios Casa Ayuntamiento, la de la Calle de las Ynfantas numero doce destinada á Carcel, la conocida por la de la Administracion para Escuelas públicas, el Matadero y carniceria, se le permita continuar en usufructo de dichos edificios... se ha servido S.M. acceder á esta petición concediendo además ...bajo el mismo caracter, la casa Teatro y la Plaza de Toros de ese Real Sitic, entendiéndose que ambas gracias son por el tiempo de su reinado..." En 1876 el Ayuntamiento solicita en usufructo los edificios que ocupa.

6. AHPM. Protocolo $n^{2} 36723, n^{\circ} 77$. Acta notarial de 21 de agosto de 1876.

76 AGP. Administraciones Patrimoniales. Aranjuez. $C^{a} 14481$. 
La tercera relación recoge las propiedades a cargo de la Administración y que no pertenecen al Real Patrimonio. Son las urbanas Convento de San Pascual, el Palacio de Baviera, el Teatro, la Plaza de Toros y habitaciones de la Iglesia de San Antonio. Las rústicas incluyen calles de árboles fuera del casco urbano, como Sotomayor y las distintas acequias (Colmenar, Tajo, Caz de las Aves...) Se exceptúa la Casa de la Montaña ya vendida. Otras propiedades enajenables sí las recupera el Monarca: Sotomayor (difícil de vender por contener la "magnifica Casa de la Monta»), El Rebollo, Legamarejo, Soto Redondo, Jembleque, la Calle Larga.

Por último, la cuarta relación recoge las fincas a cargo de la Dirección de Caminos: el Puente Colgante y el Puente Largo, por su valor en el sistema estatal de comunicaciones.

Si comparamos entre sí las Relaciones con las Actas de entrega vistas anteriormente, observamos cómo la mayor parte de las comprendidas en la relación vuelven al Patrimonio Real. La situación administrativa, aun mermados los limites, es idéntica a la de 1865. El Patrimonio Real seguirá cediendo el dominio útil de sus propiedades bien al Ayuntamiento, bien al Estado.

\subsubsection{Valoración y estado de las propiedades}

Simón Viñas nos ofrece un estado de la cuestión en un momento clave - poco antes de las Leyes de 1876-, sobre los bienes que habían constituído el Real Heredamiento en el pasado, con una dualidad en su valoración: la estética-histórica y la funcional ${ }^{77}$.

Comienza su estudio por el Palacio Real. Sus valores artísticos, históricos y culturales son obvios: "hubo un tiempo en que se pensó por el Estado convertirlo en un museo racional aunque algunos decian que su destino era el de una biblioteca". Resulta más sorprendente otra sugerencia que tuvo su respuesta de asombro en la época: "hubo quien se proponia, y se hicieron gestiones para conseguirlo, hacer de él una fábrica aprovechando el salto de aguas de la ria". Simón Viñas ensalza la sensibilidad de corte nacionalista que reacciona ante tales desaprensivas iniciativas: "Por fortuna no todos los hombres habian perdido las nociones

$"$ S. VIÑAS, Op. cit. pág. 516-538. SimON VIÑAS había tenido un gran protagonismo politico durante las Juntas revolucionarias y el Sexenio Democrático en el Ayuntamiento de Aranjuez... Ahora en su tono de defensa de la Corona subyace una motivación personal circunstancial. 
de las glorias nacionales y pudo evitarse ese borrón en nuestra historia". De la Casa del Labrador, en situación semejante, las referencias aluden al patrimonio mueble. A nivel arquitectónico no sufrió alteración alguna.

Las Casas de Oficios y de Caballeros continúan manteniéndose en sus usos, evolucionados con el tiempo pero vinculados a su razón de ser: durante un periodo se destinan a fines militares, pero desde la época de Amadeo de Saboya se dedican al establecimiento de la Administración del Real Patrimonio, que se prolonga hasta nuestros dias. Los Fogones se usan para almacenar materiales, la Casa de Infantes en parte para oficinas del Patrimonio, en parte para los empleados de categoría superior .

Las Capillas de Palacio y de San Antonio, son ahora recuperadas al culto. San Pascual no sufre modificaciones arquitectónicas ni funcionales, sigue siendo un convento, pero ocupado por órdenes diversas. Depende ahora de la Administración del Estado.

El Hospital de San Carlos es uno de los edificios más afectados por todos estos procesos: alternará momentos de abandono con variados usos, para ser ahora recuperado del olvido. También acusan cambios las Cocheras de la Reina Madre: recién recuperadas para el servicio del Monarca, acabarán vinculadas al Ejército.

Teatro y Plaza de Toros ven perjudicada su conservación por los sucesivos cambios de titularidad y arrendamientos. Serán los que mayor número de reformas de carácter arquitectónico sufran, tanto estructurales como decorativas ${ }^{78}$. Edificios regios que estaban vinculados a las diversiones dieciochescas, van perdiendo su razón de ser.

A la Plaza de San Antonio - Plaza de la Libertad en el periodo anterior- se le reconoce un nuevo valor, como escenario de aquellos acontecimientos de carácter periódico más próximos a la población (mercado, festejos, ferias, conciertos de la banda). Se convierte en el lugar de encuentro y desarrollo de unas actividades decididamente municipales y cotidianas.

Por último el conjunto de los famosos jardines seguirá un proceso de buenas intenciones que ha de luchar contra su deterioro. Mientras en el municipio se van creando pequeños espacios con vegetación, las grandes

\footnotetext{
it Ibidem, págs. 527-528; AHPM. Protocolo $n^{\circ} 36723$ no 77 y n 79 . Actas de 21 de agosto de 1876... AMAj. C C $^{2}$ 40/49 al 53, son ejemplos de la época de Alfonso XIII. Obras en la Plaza de Toros se registran en 1880-1881 y 1881 según expedientes de contratación de las mismas conservados en el Archivo Municipal de Aranjuez (AMAj. Ca 940 exp. 12 y 13, Ca 1115 exp. 5), obras en Teatro en 1885 (AMAj. C 940 exp. 14).
} 
y clásicas extensiones parecen debatirse por su supervivencia. Los daños del periodo anterior comienzan a repararse ahora. Este abandono, con grandes perdidas de arbolado, trasciende a fincas rústicas e históricas como los Sotos de Legamarejo y del Rebollo.

\subsubsection{Las propiedades en manos privadas ${ }^{79}$}

La evolución de aquellas propiedades que por la desamortización pasan a manos privadas es diferente entre las rústicas y las urbanas. La mejora se produce a mayor escala respecto de estas últimas "siendo casi todas reedificadas y rebocadas de lo que tenian necesidad" en un momento en que se desea recuperar la tradición regia y cortesana del Sitio, ese hálito festivo perdido en el paréntesis 1868-1875, y que sí parece revivir durante el periodo de Alfonso XII. El municipio a duras penas logra estar a la altura de las circunstancias. Este sueño se desvanecerá con Alfonso XIII, durante cuya minoría desaparecerán definitivamente las regias Jornadas primaverales.

No corren la misma suerte todas la fincas rústicas, generalmente en manos de la alta burguesía o la nobleza. La desamortización sería el culmen de un proceso iniciado en la epoca de Isabel II en que numerosos nobles y enriquecidos hombres de negocio deciden construir sus casas de recreo en las inmediaciones de Palacio, entonces sobre terrenos cedidos por el monarca mediante censo enfitéutico. Ahora con dominio directo sobre la propiedad, destaca el esplendor de espacios como el Jardín de la Reina y El Parnaso. Paralelamente se inicia el abandono y ruina de la mayoría de palacetes que habian ocupado principalmente el Sur y Oeste de la población, por el asentamiento de una incipiente industria en el entorno del ferrocarril. Las dos Azucareras, casi contemporáneas, responden a nuevos planteamientos en la explotación del cercano suelo agrícola.

Entre las fincas clásicas, el Real Cortijo, destaca por haber pasado por sucesivas manos, nunca rentable, ni siquiera en su fundación, motivada por las ideas fisiocráticas tan en boga en el siglo XVIII. Sin embargo, La Flamenca, desde ahora propiedad del Conde de Fernán Núñez, florecerá en esa doble vertiente agrícola y de recreo que la convierte en la más italiana de las fincas de Aranjuez, a pesar de su nombre, más cercana al concepto de villa que al de campo flamenco por el que surgió. Infantas,

14 lbidem, pégs. 536-538. 
Villamejor, Castillejo, cuarteles que se pretendía destinar para pastos de la Yeguada, ahora se conforman como colonias, en torno a las preexistentes casas de fundación regia, pero sin llegar a constituir entidades municipales. En la actualidad son pedanías y barrios, desdibujados recuerdos de la ciudad rústica que el sueño ilustrado pretendió fuese Aranjuez.

\subsubsection{La minoría de edad de Alfonso XIII (1885-1902)}

Al amparo de la normativa de 1876, cuya vigencia alcanzará la II República, se suceden las iniciativas para la recuperación de las fincas aún no devueltas a la Corona ${ }^{80}$.

La continuidad con el periodo anterior también explica la renovación de las cesiones de propiedades del Real Patrimonio al Ayuntamiento, como la Plaza de Toros y el Teatro ${ }^{81}$. Desde un primitivo uso de estos inmuebles en torno a la Corona y la Corte, estos regios festejos ahora en franca decadencia, conocerán durante las fiestas de Mayo y Septiembre un destinatario distinto: la población asentada en Aranjuez, nuevos protagonistas de unas fiestas ya de carácter popular. Aún así, el Ayuntamiento siempre tendrá la deferencia de reservar palcos para «el servicio de S.M.».

Respecto del resto de bienes inmuebles, el Ayuntamiento sólo ha logrado modificar la fórmulas iniciales de arrendamiento y alquiler por la de cesión en usufructo, iniciada en el periodo 1868-1874. Habrá que esperar a la última década del siglo para que el Ayuntamiento inicie la posesión de sus primeros bienes ${ }^{82}$ - Casa Pontejos, Casa Tastas, Mercado de Abastos-. El último es construido por iniciativa del gobierno local (1891$1895)$, en respuesta a las necesidades de un núcleo poblacional que es el mayor de la comarca. El edificio levantado en el ámbito decimonónico de la Plaza de la Constitución, realizado con una arquitectura que pretende desvincularse de la tradición clásica tan manifiesta en el Real Sitio y que se expresa en el lenguaje del siglo que termina, mediante el empleo del hierro, se erigirá en símbolo del Aranjuez Municipal.

El resto de edificios usados por el municipio, provienen de una cesión del Estado de unos bienes que a su vez procedían del Patrimonio de la Corona. $Y$ es que ahora la nómina de edificios de uso público destinados

so AGP. Administraciones Patrimoniales. Aranjuez. C 14481 lg. 143.

H' AHPM. Protocolo $n^{0} 36736, n^{\circ} 46$, de 13 de abril de 1889. AMAj. C ${ }^{a}$ 940/49 al 53. Son expedientes de arrendamiento del Teatro en estas fechas de 1887-1889, en que se desarrollan las últimas de las Jornadas. 
a servicios se aumenta a costa del Patrimonio Real. Tal es el ejemplo de las conocidas Cocheras de La Reina Madre Isabel de Farnesio. Devueltas al Patrimonio en 1876, ahora se usarán como Colegio para Huérfanas de Infanteria. Esta presencia del Estado interesa al Ayuntamiento. Cuando las Jornadas de Primavera están a punto de desaparecer ${ }^{83}$, siempre cabe la posibilidad de afluencia de gente de alto nivel adquisitivo y el potencial incremento de ingresos en las arcas municipales ${ }^{84}$.

Se ansía un mayor dinamismo en un lugar que va perdiendo su vida, olvidado por las altas esferas sociales a medida que un grupo social de corte burgués, más próximo a las clases medias o que aún no alcanza a la alta burguesía, pero con ciertos recursos, comienza a mostrar un interés por el Real Sitio, que justifica excursiones y visitas que anuncian el siglo $x \times$ como el siglo del turismo.

\subsubsection{Alfonso XIII (1902-1931): La llegada del siglo XX}

El proceso iniciado en 1885 se consolida a principios del siglo $X X$. Patrimonio Real y Ayuntamiento procederán a inscribir sus bienes inmuebles en el Registro de la Propiedad.

Respecto del Patrimonio del Ayuntamiento, el Archivo Municipal de Aranjuez ${ }^{85}$ custodia inventarios y títulos de propiedad que señalan un incremento de fincas en la última década del XIX y primeros años del nuevo siglo. Sumará terrenos pequeños, vinculados a necesidades de la población (tranzones en la Huerta de Secano, El Aljibe, en el término de Ocaña, para abasto de aguas potables, parcelas en la Telegrafía y en la Dehesa del Montecillo).

82 AMAj. C a $^{\mathbf{3}}$ 507/6, C $\mathrm{C}^{\mathrm{a}}$ 507/1. Una idea del mantenimiento de la situación vemos en 1890: "Inventario de todos los bienes, valores y derechos pertenecientes a este Real Sitio que se forma con arreglo al Real Decreto de diez y seis de Diciembre de 1889\%. Recoge la relación harto conocida: Casa Consistorial, Cárcel, Matadero, Cementerio, Escuelas Públicas, y una observación: "estos cinco edificios han sido cedidos por el Estado al Municipio en usufructo mientras estén destinados a los servicios que hoy tienen".

H3 AGP. Administraciones Patrimoniales. Aranjuez. C $C^{\text {a }}$ 14491, reseña Jornadas aún en 1887. Hacia 1890 se suprimen definitivamente.

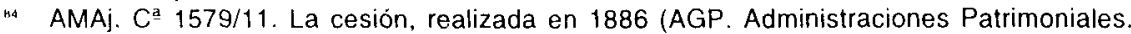
Aranjuez. $C^{a}$ 14494) tendrá repercusiones que trascenderán a la propia configuración urbana. El edificio se ampliara a costa de la contigua Plaza de Abastos.

"El "Elinventario de los titulos de propiedad de las fincas correspondientes al llustrismo Ayuntamiento de Aranjuez" (AMAj. Ca 507/1) reseña las propiedades que van a inscribirse en el Registro de la Propiedad a favor del Ayuntamiento. Para los traslados de escrituras AMAj. Ca 507 , C 776 y $C^{\mathbf{a}} 1107$. 
Por otra parte, un expediente iniciado en $1905^{86}$, respondiendo a la Ley Hipotecaria aprobada con la Restauración, con cierto retraso por "haberse estado mejorando y embelleciendo todos los Sitios Reales", logrará la inscripción de las fincas del Patrimonio Real — con los límites que ahora trae, salvados todos los avatares del siglo $X I X-y$ con ello el fin de todo un proceso que se inició con la indefinición tanto conceptual como geográfica y jurídica de los bienes en posesión de la Corona cien años antes. Sólo el final de la Restauración, con el advenimiento de la II República, en un proceso que recuerda al de 1868, modificará la situación, a través de la incautación de los bienes que constituyen el Patrimonio Real ${ }^{87}$. Pero esto ya corresponde a la historia del siglo XX.

No obstante los cambios de titularidad de bienes, en los que no se tiene en cuenta al municipio, respetarán el conjunto de un patrimonio, bien de la Corona, de la República o Nacional, ya definido y diferenciado con independencia de los cambios políticos, siempre contemplado en el conjunto del Patrimonio del Estado y reconocido por su significado testimonial e histórico, desde la valoración estética y funcional de las propiedades.

AGP. Administraciones Patrimoniales. Aranjuez. C $C^{\text {a }}$ 274/5. Una Relación de las Propiedades que constituyen el Real Patrimonio de Aranjuez recoge la totalidad de posesiones: jardines, Plaza de San Antonio, paseos, los ya famosos Tranzones de las Doce Calles que definitivamente recupera el Patrimonio, incluso los enclaves en otros términos (Xembleque, Soto Redondo, Puente de Aceca) asi como presas, caces, traidas de aguas que no pasan al Estado.

y7 Acta de incautación de 27 de abril de 193t (AGP. Administraciones Patrimoniales. Aranjuez. C 2838/2). Un Expediente de cesión de fincas urbanas de 1932 (AGP. Administraciones Patrimoniales. Aranjuez. C ${ }^{a}$ 2842/3) muestra la cesión, por parte del Patrimonio de la República, una serie de fincas - todas urbanas - a diferentes centros e instituciones. 